Page 581-592. ISBN: 978-602-6 988-75-1

Web Jurnal Online: jurnal.unmuhjember.ac.id

By: Hofifatus Zaina, Itok Wicaksono

Implementation Of RT/RW Formation Policy As A Village Community Institution

\title{
IMPLEMENTATION OF RT / RW FORMATION POLICY AS A VILLAGE COMMUNITY INSTITUTION
}

(Studi Desa Sukorejo Kecamatan Sumber Wringin Kabupaten Bondowoso Tahun 2018)

\author{
Hofifatus Zaina \\ Itok Wicaksono, \\ Program Studi Ilmu Pemerintahan \\ Fakultas Ilmu Sosial dan Ilmu PolitikUniversitas Muhammadiyah Jember \\ Email: itokwic4ksono@gmail.com
}

\begin{abstract}
This study aims to describe the implementation or implementation of regulations on RT / RW as a Village Community Institution in Sukorejo Village, Sumber Wringin District, Bondowoso Regency in accordance with Regional Regulation Bondowoso No. 13 of 2014 concerning Guidelines for the Establishment of Village Community Institutions. The locations of focus of attention in this study were the Office of Community and Village Empowerment of Bondowoso Regency, and Sekorejo Village, Sumber Wringin Subdistrict, Bondowoso Regency in charge of the Neighborhood and Neighborhood Unit (RT / RW) within the Regional and Village Governments. This research method uses a qualitative approach. The technique of determining the sample of this study using Purposive Sampling is the sample taken based on certain priorities and considerations. Data collection techniques through interviews, observation, and documentation. The data used are primary data and secondary data. This study refers to a theory based on the opinion of Edwads III (1980: 10) that the implementation includes communication factors, resources, dispositions and bureaucratic structures. The results of research or data findings, both primary and secondary data, it can be stated that the Implementation of the RT / RW Formation Policy as a Social Institution in Bondowoso Regency especially the Community Empowerment Office and Bondowoso Regency and Sukorejo Village Sumber Wringin District Bondowoso Regency is still less than the maximum, due to the Government Regional and Village Governments have not been able to fully carry out well the four aspects used as benchmarks in the Implementation of the Policy on the Establishment of RT / RW as Village Community Institutions.
\end{abstract}

Keywords: Implementation, Policy, Village Community Institutions, RT / RW. 
Page 581-592. ISBN: 978-602-6 988-75-1

Web Jurnal Online: jurnal.unmuhjember.ac.id

By: Hofifatus Zaina, Itok Wicaksono

Implementation Of RT/RW Formation Policy As A Village Community Institution

\section{INTRODUCTION}

Quoting according to Selo Sumarjan in his article, actually at the rural level we know the system of village and neighboring neighborhoods which were originally set in Yogyakarta at the time of Sultan Hamengku Buwono IX. At that time, the Rukun Tetangga (RT) was known as tonarigumi, which was used by the Japanese government to mobilize the population for warfare against allies and to make the Chairman of the RT (Gumichoo) a people's watchdog which was one of the Community Institutions in the village or village area. The neighborhood and neighborhood harmony system was originally held in the city of Yogyakarta alone, after Indonesia gained independence the village and neighborhood harmony system was spread throughout Indonesia and until now has become an inseparable part of the village administration in the city and the village administration outside the city (Guntur Subing, Portrait Blur Language-Culture Lampung).

Rukun Tetangga (RT) and Rukun Warga (RW) in Indonesia are one of the village social institutions (LDK). Village community institutions themselves are regulated in the Minister of Home Affairs Regulation of the Republic of Indonesia Number 18 of 2018 concerning Village Social Institutions and Village Traditional Institutions, which were originally regulated in Minister of Domestic Affairs Regulation Number 5 of 2007 concerning Guidelines for Structuring of Social Institutions, but are considered to be incompatible with developments that need to be replaced with Permendagri Number 18 Year 2018. Permendagri Number 18 Year 2018, states that the Village Community Institution, hereinafter abbreviated as LKD is a forum for community participation, as a partner of the Village Government, participates in planning, implementation and supervision of development, as well as improving community services Village and inside there are also types of LKD, one of which is RT and RW. Rukun Warga (RW) One form of community organization created based on the division of territory. The formation of RWs consisting of several RTs is carried out with community deliberations or RT managers and determined by the village or kelurahan. Rukun Tetangga (RT) is a form of community organization whose territory is under the Rukun Warga (RW). The Rukun Tetangga and Rukun Warga organizations are not mentioned and are not included in the government system, and their formation is through local community consultations in the context of community services and in accordance with community needs. The Rukun Tetangga and Rukun Warga are led by the RW Chairperson and the RT Chairperson are both elected by residents around the RW and surrounding RT.

Rukun Tetangga (RT) and Rukun Warga (RW) are the lowest and closest organizations to the community and understand the conditions and problems faced by the community in their environment. The existence of RT / RW is expected to be able to help carry out the role of government in providing maximum services to the community in their environment, one form of service provided by RT / RW is a cover letter. Administrative services through the Cover Letter RT and RW which is very helpful for the government, especially in early detection and protect against potential misidentification of the status of residence of citizens served, so that RT and RW can be called the spearhead of government administration. The position of RT and RW is the 
Page 581-592. ISBN: 978-602-6 988-75-1

Web Jurnal Online: jurnal.unmuhjember.ac.id

By: Hofifatus Zaina, Itok Wicaksono

Implementation Of RT/RW Formation Policy As A Village Community Institution

smallest base of government in addition to the heavy duty, but the position of RT and RW is still underestimated, while in Permendagri Number 18 of 2018 article 13 reads about the Governor, Regents / Mayors and Camats conducting guidance and supervision of the formation, empowerment and utilization of LKD and LAD as village government partners in the region, one of which is RT and RW. The Government of Bondowoso Regency also regulates the Village Community Institutions through the Regional Regulation of Bondowoso District Number 13 of 2014 concerning the Guidelines for the Establishment of Village Community Institutions, which also regulates the formation of RTs and RWs. Regional Regulation of Bondowoso Regency Number 13 of 2014 Article 11 states that RT and RW have the task of assisting the Village Government in carrying out government affairs. RT / RW Management plays an active role in supporting the vision and mission of regional government development, RT / RW is able to be a dynamic coordinator for increasing community participation in improving government services, development, and community empowerment, playing a role in environmental management, becoming a facilitator who can maintain communication and harmonizing programs -programs from government to the community or vice versa provide input to the government in an objective, optimal and sustainable manner in accordance with applicable mechanisms, and RT / RW plays an important role in collecting public funds both tax and non-tax.

Bondowoso Regency is one of the underdeveloped districts in East Java Province based on the 2015-2019 RPJMN. There are four factors that have a bearing on the results of the East Java Central Statistics Agency

\section{THEORETICAL FRAMEWORK}

\section{Public Policy Implementation}

Goerge C. Edward III (in Tahir. A, 2015: 61-71) said that in the study approach to policy implementation the abstract statement starts from how the pre-conditions for the success of public policy and second is what are the main obstacles to the success of public policy, to answer important questions that, then Edwards III offers and considers four factors in implementing public policies namely Communication, Resourches, Dispotition or Attitudes, and Bureaucratic Structure. Which will be further ringed below.

\section{a. Communication}

Edward III (1980: 10) in Tahir's book. A emphasized that the implementation of the policy can run effectively, so those who must be responsible for the implementation of a policy must know what needs to be done. The order to implement the policy must be conveyed clearly, accurately, and consistently to those who are capable. If the policy implementation expected by policymakers appears to be clearly specified, there may be a misunderstanding by the designated implementers. It is very clear that the confusion experienced by the implementers regarding the problem that must be done can provide an opportunity to not implement the policy as desired by the mandate giver.

\section{b. Resource}

Policies have been clearly and consistently communicated, but if the implementor lacks the resources to carry out, then the implementation will not be effective. Important resources include staff in the right size with the necessary expertise, sufficient and 
relevant information on how to implement the policy and in other adjustments involved in implementation. Insufficient resources will mean that laws will not be enforced, services will not be provided, and appropriate regulations will not be developed. The resource factor has an important role in the implementation of the policy, because however clear and consistent the provisions or rules of a policy are, if the personnel responsible for implementing the policy lack the resources to carry out work effectively then the policy will not be effective. In addition, there must be accuracy or appropriateness between the number of staff needed and the expertise that must be possessed by the tasks to be done. Funds to finance the operation of the implementation of the policy, relevant information and which covers how to implement a policy, and the willingness or ability of various parties involved in the implementation.

\section{c. Disposition}

The third factor as consideration in implementing policies according to Edward III (1980: 10) in Tahir's book. A emphasized: The attitude of the implementer is a third important factor in the approach regarding the study of public policy implementation. Policy implementation is expected to be effective, policy implementers must not only know what needs to be done and have the capability to implement it but must also have the desire to implement the policy. Most implementers use authority wherever possible in implementing a policy. One reason for this is that they are independent of policy makers. Another reason is the complexity of the policy itself although other ways the implementers use their authority depends on the disposition of those who refer to these policies, but ultimately it is their attitude that influences their perspective on the policy and how they see the policy will have an impact on the interests individuals and organizations.

\section{d. Bureaucratic Structure}

Edward III (1980: 10) in Tahir's book. A explained: Even though the resources to implement the policy were sufficient and the implementers knew what had to be done and were willing to carry out the policy implementation, it was still hampered by the inefficiency of the bureaucratic structure. Organizational fragmentation can hamper the coordination needed for the successful complexity of implementing a policy that requires collaboration with many people. This results in the wasting of scarce resources, closing opportunities, creating confusion, leading policies to produce cross-purposes, and causing important functions to be forgotten.

\section{RESEARCH METHODS}

\section{Type of Research}

This research used descriptive qualitative research type, namely research aimed at wanting to describe certain social phenomena (Kahar Haerah, 2016. Social Research Methodology. Muhammadiyah University Faculty of Social Sciences, Jember). The phenomenon to be described is related to the implementation of the policy on the Establishment of RT / RW as a Village Community Organization (Study of Sukorejo Village, Sumber Wringin District, Bondowoso Regency in 2018). The approach used in 
Page 581-592. ISBN: 978-602-6 988-75-1

Web Jurnal Online: jurnal.unmuhjember.ac.id

By: Hofifatus Zaina, Itok Wicaksono

Implementation Of RT/RW Formation Policy As A Village Community Institution

describing the phenomenon is a case study which only applies to the case, does not apply to other cases.

\section{Research Location and Time}

This study is the location of the study is Bondowoso Regency with the consideration that Bondowoso Regency is one of the underdeveloped districts in East Java Province, especially weak on the quality of its human resources. The locations of focus of attention in this study were the Office of Community and Village Empowerment of Bondowoso Regency, and Sekorejo Village, Sumber Wringin Subdistrict, Bondowoso Regency in charge of the RT / RW section within the scope of Regional and Village Governments. The time to carry out this research starts from January to finish

\section{Data Sources}

This study uses a sampling technique by using the "Purposive Sampling" informants selected at the beginning of the study, namely: (1) Head of Village Empowerment Section (Office of Community and Village Empowerment), (2) Head of Village Institutional and Village Section (Office of Community and Village Empowerment) ), (3) Program, Evaluation and Financial Subdivision (Office of Community and Village Empowerment) (4) Sukorejo Village Head Sumber Wringin District Bondowoso District, (5) Village Apparatus, (6) RT / RW in Sukorejo Village Sumber Wringin District Bondowoso.

\section{Data Collection Method}

In this study using data collection techniques, namely: interviews, observation, and documentation

\section{Data Analysis Methods}

Data analysis techniques in this study used descriptive qualitative. With the following interactive analysis cycle: data collection, data reduction, data presentation, and drawing conclusions.

\section{Data Validity}

Test the validity of the data in research is often only emphasized on the validity and reliability test. This qualitative research, findings or data can be declared valid if there is no difference between what the researcher reports and what actually happens to the object under study. Triangulation is the most commonly used method of guaranteeing the validity of data in qualitative research. Trianggulation is a technique for checking the validity of data by utilizing something other than the data for the purposes of checking the data or as a comparison of the data.

\section{RESULTS AND DISCUSSION}

\section{Implementing policies on the formation of RT/RW as Village Community Institutions}

Observation activities that have been carried out in the research can be seen that in implementing this policy the executor is the Government as the policy maker, the executive board of the Neighborhood Association and the Community Unit as the Implementer who is responsible and directly related to the community and the Community itself as a member of the Neighborhood Association and Community Associate the. The achievement of the objectives of this policy is made, each element of 
Page 581-592. ISBN: 978-602-6 988-75-1

Web Jurnal Online: jurnal.unmuhjember.ac.id

By: Hofifatus Zaina, Itok Wicaksono

Implementation Of RT/RW Formation Policy As A Village Community Institution

the implementer must necessarily cooperate in order to create a match between the objectives and implementation of this policy. To answer whether the implementation of the policy on the formation of RT / RW as a Village Community Organization has been carried out appropriately based on the opinion of Edwads III (1980: 10) by considering the following four factors.

\section{a. Communication}

1. Transmission

Transmission in this case explains the Policy on Village Community Institutions which regulates RT / RW in general, which is set in the Minister of Domestic Affairs Regulation No. 5 of 2007 concerning Guidelines for the Arrangement of Community Institutions Stipulated in Jakarta on 5 February 2007, which was later updated with Regulation of the Minister of Home Affairs of the Republic of Indonesia Number 18 Year 2018 Concerning Village Community Institutions and Village Customary Institutions promulgated in Jakarta on April 27, 2018. Bondowoso Regency Regional Regulation governing Village Community Institutions, particularly RT / RW, namely Regional Regulations Bondowoso Number 13 of 2014 concerning the Guidelines for the Establishment of Village Community Institutions promulgated in Bondowoso on 27 March 2015. It can be seen that the Regulation of the Minister of Home Affairs of the Republic of Indonesia Number 18 of 2018 is still ratified recently, while the Regional Regulation of Bondowoso Regency Number 13 of 2014 has h was ratified in 2015. So it can be concluded that the Regional Regulation of Bondowoso District Number 13 of 2014 still refers to the Minister of Home Affairs Regulation Number 5 of 2007.

\section{Clarity}

Regional Regulation of Bondowoso Regency Number 13 of 2014 concerning Guidelines for the Establishment of Village Community Institutions has explained about the Formation of RT / RW, RT and RW management, Requirements for RT and RW management, Task for RT and RW Management, to RT and RW management functions and even regarding guidance and supervision LKD, one of which is RT / RW. The task of the government is to explain or communicate to the community or RT and RW about the above. As explained in the Regional Regulation of Bondowoso District Number 13 of 2014 Article 40 paragraph 1 that the Regional Government is obliged to foster and supervise LKD, one of which is RT and RW. The policy must be accepted by the policy implementers in this case RT and RW through the process of coaching or with socialization and training which is one of the responsibilities of local governments.

The results of interviews that the district government or the Office of Community and Village Empowerment submitted directly to the village government to carry out coaching activities for RT / RW. Supervision from the Community and Village Empowerment Office only through the reported budget.

The results of interviews with the Village Head and one of the RTs that the lack of clarity in the implementation of this regulation lies in coaching activities for the RT / RW that are not explained or there is no mandate must be done several times. 
Page 581-592. ISBN: 978-602-6 988-75-1

Web Jurnal Online: jurnal.unmuhjember.ac.id

By: Hofifatus Zaina, Itok Wicaksono

Implementation Of RT/RW Formation Policy As A Village Community Institution

\section{Consistency}

The government must be consistent with the policies that have been agreed upon together. The policy regarding RT and RW Decrees is explained in article 9 paragraph 10 and 11 that the results of the selection and filling of RT and RW management are outlined in the Minutes and Reported to the Village Head to be determined and validated by the Decree of the Village Head and reported to the Regent through Camat Bondowoso District Regulation Number 81 Year 2016 concerning the position, organizational structure, duties and functions and work procedures of the Bondowoso Regency Community and Village Empowerment Office, article 2 "The Community and Village Empowerment Office of Bondowoso Regency has the task of assisting the Regent in carrying out government affairs which are the regional authority in the Field Community and Village Empowerment and assistance tasks given to the Regency ".

Article 41 explains that the Regional Government is responsible for developing and supervising LDK implementation and providing technical guidelines for implementing and developing LDK, while at the sub-district level that facilitates the implementation of LDK tasks, functions and obligations. In fact, the Regional Government handed over the RT / RW development activities to the village directly on the grounds of effectiveness and efficiency. The coaching activity in 2018 was attended by representatives from the sub-district as presenters as well as overseeing the activities.

Article 9 paragraph 11 of the regulation regarding the service period of RT and RW management is deemed incompatible with the community's condition because the appointment and replacement of RT and RW management is based on the suitability of the RT and RW management for the community regardless of the service and education period as stated in the requirements of RT and RT management. RW Substitution or selection of RT / RW does not follow the existing regulations that the RT service period and RW Management for 5 (five) years and can be re-elected at most 3 (three) times in a row or not in a row (Based on Regional Regulations Bondowoso Regency Number 13 of 2014 concerning Guidelines for the Establishment of Village Community Institutions, article 9 paragraph 11). This illustrates that there are inconsistencies in this regulation, because the government is still weak in communicating to the community, besides that there is no action from the sub-district or district level in this situation.

\section{b. Resource}

1. Apparatus Resources

In terms of the availability of human resources, the Bondowoso Regency Community and Village Empowerment Office is based on data in the staffing structure in the 2018-2023 Bondowoso District Community and Village Empowerment Document Planning Office and has insufficient staff when viewed from the activities that must be carried out. The number of employees of the Community and Village Empowerment Office of Bondowoso Regency in 2018 totaled 38 employees, with the most staff positions being in the staff positions of 23 people, while the structural positions were 15 people. If seen from the education table the number of employees with $\mathrm{S} 2$ is 5,11 are $\mathrm{S} 1$, 
Page 581-592. ISBN: 978-602-6 988-75-1

Web Jurnal Online: jurnal.unmuhjember.ac.id By: Hofifatus Zaina, Itok Wicaksono

Implementation Of RT/RW Formation Policy As A Village Community Institution

DIII is 1 , and SMA is 21 employees. So, we can conclude that the education level of employees at the 2018 Bondowoso District Community Empowerment and Village Empowerment Office is more dominated by high school-educated staff, so it can be said that resources are still lacking. If based on group, the most group is group III with 19, while group II has 15 people and group I has 4 people.

Sukorejo Village Apparatus Data Sumberwringin District Bondowoso Regency in 2018 that the village apparatus with high school / vocational / equivalent education is 10 village apparatuses, 9 village apparatus with $\mathrm{C}$ package education, the village apparatus with junior high school education is 1 person, namely the village head Sukorejo, while one with a B-level education apparatus. If we look at it in terms of the education of the Sukorejo Village Apparatus, the HR of the village apparatus itself is still inadequate because none of the devices have a Bachelor's degree education or a University graduate.

List of names of the Head of the Neighborhood Association (RT) of Sukorejo Village, Sumber Wringin District, Bondowoso Regency in 2018, amounting to 39 RT. Whereas the average education level of the majority of the RT Head of Sukorejo Village is primary school graduates, with 36 RTs with elementary education, 2 other RTs having SMP / SLTP education and 1 RT having Package B. Of the total of 9 RWs with 7 RWs and 7 RWs with SD and 2 people with a junior/senior high school education. Whereas the requirements for RT and RW Management in Bondowoso District Regulation Number 13 of 2014 article 10 are the lowest educated junior high school (SLTP) or equivalent. In this case, it means that the resources of the RT and RW management have not fulfilled the regulations that have been made by the government.

Through the data and description above, it can be concluded that the apparatus resources from the Dinas, Village level, up to the RT and RW levels are still inadequate. The Dinas level itself is still equivalent to the Village which has the most educated apparatus at an average high school level. The majority of RT and RW levels have an elementary school education, so the expectation of the emergence of competent and integrated government officials is still felt low.

\section{Fund Budget}

Bondowoso Regent Regulation Number 71 Year 2017 describes the Procedures for Allocation, Distribution, Utilization, Monitoring and Evaluation of Bondowoso Regency Village Fund Allocation for Fiscal Year 2018 in articles 13 and 14, that the operation of each RT / RW is set at Rp. 420,000.00 per year per institution to assist the implementation of government service tasks, development planning, peace and order, and empowerment of rural communities.

Info graph of APBDesa Sukorejo Village, Sumber Wringin Subdistrict, Bondowoso Regency, is explained in the area of community development budgeted for 33,850,000.00, one of which is for RT / RW development activities. Whereas, RT / RW Operational Activities in the expenditure section are budgeted for 20,160,000.00. APBDesa itself is a budget for one year. The operational budget for RT / RW activities for a year of 20,160,000.00 with a total of 39 RTs and 9 RWs will be in accordance with the Regulations of Bondowoso Regent Number 71 of 2017 concerning Procedures for Allocation, Distribution, Utilization, Monitoring and Evaluation of Village Fund 
Page 581-592. ISBN: 978-602-6 988-75-1

Web Jurnal Online: jurnal.unmuhjember.ac.id

By: Hofifatus Zaina, Itok Wicaksono

Implementation Of RT/RW Formation Policy As A Village Community Institution

Allocation for Bondowoso Regency Budget Year 2018 in articles 13 and 14, that the operation of each RT / RW is set at Rp. 420,000.00 per year per institution to assist the implementation of government service tasks, development planning, peace and order, and empowerment of rural communities. However, the funding resources are still considered not good from the district or RT level, they still feel lacking with funds of Rp. 420,000.00 per year per institution, even though it is already regulated in the Regulations of the Regent.

\section{c. Disposition}

Observation results, the Bondowoso District Community and Village Empowerment Agency does not pay much attention and oversee Village Community Institutions, especially RT / RW, this can be seen from the work plans and work programs in the Field of Village Empowerment, the Institutional Section and Village Government. The 2018 work plan explains that one of the work plans is the percentage of villages that are in an orderly administration of the village administration, so that all village officials must understand how to carry out good and correct government administration. This can be achieved with direct technical guidance or guidance. The district government or the Office of Community and Village Empowerment submits directly to the village Government to carry out development activities for RT / RW, while supervision from the Office of Community and Village Empowerment is only through the reported budget.

The work plan of the Bondowoso Regency Community and Village Empowerment Office, in the Village Government Development Program there is no official activity program that specializes in the development of RT / RW, as long as PKK guidance is listed in the activity plan where PKK is one of the Village Community Institutions equal to RT / RW RW However, there is the Technical Implementation Bimtek of Village Financial Management.

Disposition in Sukorejo Village Sumber Wringin Subdistrict Bondowoso Regency, based on observations by researchers Village government was less assertive towards the community and underestimated the replacement of RT / RW, even though in the regulations it was explained that the selection of RT and RW was done by deliberation to reach consensus by RT residents and residents The RW (represented by the RT) is facilitated by the Village Head or Acting Village Head. Meanwhile, the village government itself did not carry out the facilitation and did not give orders to hold deliberations to the community. Finally, the RT / RW was only adopted or replaced by one of the communities considered suitable to be an RT / RW based on the views of the village government without following the existing rules.

\section{d. Bureaucratic Structure}

Village Community Institutions, especially RT / RW, in the organizational structure or organizational structure of the Office of Community and Village Empowerment Bondowoso District there is a Field of Village Empowerment which has the task of implementing and coordinating village empowerment activities in the field of institutional, governance, improvement of village facilities and infrastructure, strengthening village economy and the development of village apparatus resources. Its 
Page 581-592. ISBN: 978-602-6 988-75-1

Web Jurnal Online: jurnal.unmuhjember.ac.id

By: Hofifatus Zaina, Itok Wicaksono

Implementation Of RT/RW Formation Policy As A Village Community Institution

function is as a formulator of technical technical institutions, village and village government, as well as formulating and preparing policies to facilitate the implementation of human resource programs. In the field of Village Empowerment, there is an Institutional Section and the Village Government has duties related to the Village Community Institutions, namely 1) Implementing and preparing the formulation of policies to facilitate community and village government institutional implementation, formulating facilitation for the implementation of human resource development in the framework of implementation as the task of village empowerment. 2) Plan monitoring and evaluation activities of village and village institutions.

Sukorejo Village Government Work Procedure explains that the task of the village government which has a part in facilitating the formation and development of the Rukun Tetangga (RT) / Rukun Warga (RW) is the government section. The division of tasks is clear, even regulated in Bondowoso District Regulation Number 35 Year 2015 Concerning the Implementation of Bondowoso District Regional Regulation Number 6 Year 2014 Regarding Guidelines for Organization and Administration of Village Governments, but the apparatus that gets the task has carried out the task or not, must be considered also.

The conclusion can be drawn that the bureaucratic structure here is clear in terms of structure and division of tasks. But the bureaucracy that runs the structure is the problem in this bureaucratic structure.

\section{COVER}

In this chapter, the author provides the final conclusions of this study, as well as providing advice to related parties, especially towards the implementation of the policy on the formation of RT / RW as Village Community Institutions in Bondowoso Regency. 
Page 581-592. ISBN: 978-602-6 988-75-1

Web Jurnal Online: jurnal.unmuhjember.ac.id

By: Hofifatus Zaina, Itok Wicaksono

Implementation Of RT/RW Formation Policy As A Village Community Institution

\section{CONCLUSIONS}

Implementation of RT / RW Establishment Policy as a Village Community Institution which refers more to Bondowoso District Regulation Number 13 of 2014 concerning Guidelines for the Establishment of Village Community Institutions, based on the results of research by observation, interviews and documentation based on the opinion of Edwads III (1980: 10) which includes communication, resources, disposition and bureaucratic structure. So the writer can conclude that the Implementation of RT / RW Formation Policy as a Social Institution in Bondowoso Regency, especially the Community Empowerment Office and Bondowoso Regency and Sukorejo Village, Sumber Wringin District, Bondowoso Regency is still not optimal. This is due to the fact that the Regional Government and the Village Government have not been able to fully implement the four aspects that are used as benchmarks in the Implementation of the Policy on the Establishment of RT / RW as a Village Community Organization.

\section{Suggestions}

Based on the description that the author has stated above, the writer can suggest the following things in order to implement the policy for the Establishment of RT / RW as a Village Community Institution that refers more to Bondowoso District Regulation Number 13 of 2014 concerning Guidelines for Establishing a Village Community Institution properly: Local Government does not underestimate the role of RT / RW as a Village Community Institution, so that the Regional Government is more responsible for the implementation of a policy that has been prepared by implementing it in accordance with the regulations that have been made. Local, Subdistrict and Village Governments coordinate with each other in the socialization of Bondowoso District Regulation No. 13 of 2014 concerning Guidelines for the Establishment of Village Community Institutions, especially regarding RT / RW. Strengthening regional regulations with regent and village regulations needs to be upheld and clarified so that there is no implementation of the formation of RT / RW that deviates from the regulations because there are no clearer guidelines. The government is more aware of the main tasks and functions (TUPOKSI) in the governance structure for the creation of good governance and good society so that Bondowoso Regency and Sukorejo Village in particular, can become developed regions. 
Proceeding ICOGISS 2019

Page 581-592. ISBN: 978-602-6 988-75-1

Web Jurnal Online: jurnal.unmuhjember.ac.id

By: Hofifatus Zaina, Itok Wicaksono

Implementation Of RT/RW Formation Policy As A Village Community Institution

\section{REFERENCE}

\section{Sumber buku:}

Tahir, A. (2015). Kebijakan Publik \& Transparansi Penyelenggaraan Pemerintah Daerah. Alfabeta: Bandung

Soemardjan, Selo. 1991. Perubahan Sosial di yogyakarta, terj. H.J. Koesoemanto dan mochtar Pabotingi. Yogyakarta: Gajah Mada University Press.

Haerah, K. (2016). Materi Kuliah Metodologi Penelitian Sosial. Jember: Universitas Muhammadiyah Jember.

Syafiie, Inu Kencana. 2007. Manajemen Pemerintahan. Jakarta: PT. Perca

Sumber Internet: 